\title{
Inhibition of the inflammatory cytokine tumor necrosis factor-alpha with etanercept provides protection against lethal H1N1 influenza infection in mice
}

Xunlong Shi', Wei Zhou ${ }^{2}$, Hai Huang ${ }^{1}$, Hongguang Zhu ${ }^{3}$, Pei Zhou ${ }^{1}$, Haiyan Zhu ${ }^{{ }^{*}}$ and Dianwen Ju${ }^{*}$

\begin{abstract}
Introduction: Factors implicated in influenza-mediated morbidity and mortality include robust cytokine production (cytokine storm), excessive inflammatory infiltrates, and virus-induced tissue destruction. Tumor necrosis factor-alpha (TNF-a) is an important pro-inflammatory cytokine present during influenza infection, but it is unclear whether direct inhibition of TNF-a can elicit protection against influenza infection.
\end{abstract}

Methods: In this study, the commercially available TNF-a inhibitor etanercept was used to inhibit TNF-a induced by lethal A/FM/1/47 (H1N1) influenza virus infection of mice. The effects of TNF-a inhibition on mouse survival, pathologic changes, immune cell infiltration, inflammatory cytokine secretion, Toll-like receptor expression, and activation of the NF-kB (nuclear factor kappa B) signaling pathway were evaluated.

Results: The intranasal delivery of etanercept provided significant protection against mortality (30\% of mice survived up to 14 days after infection) in mice treated with etanercept. In contrast, no survivors were found beyond 6 days in mice treated with saline after lethal challenge with H1N1 influenza virus. It was observed that etanercept significantly reduced inflammatory cell infiltration (for example, macrophages and neutrophils), inflammatory cytokine secretion (for example, interleukin-6, TNF-a, and interferon gamma), and expression of Toll-like receptors ( $T L R-3, T L R-4$, and TLR-7). Etanercept also downregulated and inhibited the cascade proteins of the NF-KB signaling pathway (for example, MyD88, TRIF, NF-KB, and p65), as well as enhanced host control of virus replication.

Conclusions: These findings indicate that etanercept, by blocking TNF-a, can significantly downregulate excessive inflammatory immune responses and provide protection against lethal influenza infection, making its use a novel strategy for controlling severe influenza-induced viral pneumonia.

\section{Introduction}

Influenza viruses are a major contributor to morbidity and mortality in humans, and with their ability to cause yearly epidemics and occasional pandemics, they represent a considerable burden to healthcare systems globally [1]. The recent emergence of the avian influenza A (H5N1) virus, the 2009 pandemic influenza A (H1N1) virus, and the novel avian influenza A H7N9 virus [2-4] served to highlight that respiratory viruses are important causative agents of severe pneumonia. The current battery of

\footnotetext{
* Correspondence: hyzhu@mail.shcnc.ac.cn; dianwenju@fudan.edu.cn ${ }^{1}$ Department of Biosynthesis, School of Pharmacy, Fudan University, 826 Zhangheng Road, Shanghai 201203, China

Full list of author information is available at the end of the article
}

antivirals available in clinical practice for the treatment of viral pneumonia is limited [5]. Thus, the continued pandemic threat of these circulating viruses makes the identification and the development of novel therapeutic strategies an urgent matter.

Factors implicated in the high morbidity and mortality associated with influenza virus infection include, but are not limited to, a robust cytokine production (cytokine storm), excessive inflammatory infiltrates, virusnduced tissue destruction [6], and secondary bacterial coinfection [7]. Among these factors, the excessive cytokine response is considered to be the key contributor [8].

Corticosteroids and cyclooxygenase-2 (COX-2), which are both inhibitors of inflammation, have been tested as 
inhibitors of influenza virus-induced immunopathology, although their effectiveness was shown to be limited [9-11]. Other novel immunomodulatory drugs, such as sphingosine-1-phosphate receptors analogs, have been reported to provide protection against pathogenic influenza virus by suppressing the cytokine storm $[12,13]$. Therefore, effective inhibition of inflammation appears to be a promising therapeutic strategy for respiratory virus infections.

TNF- $\alpha$, an important inflammatory cytokine, has been shown to correlate with morbidity and mortality in macaques [14] and humans [15,16] infected with highly virulent influenza viruses. However, the role of TNF- $\alpha$ in virus clearance and immunopathologic lung injuries during influenza virus infection is still controversial, and whether direct inhibition of TNF- $\alpha$ can elicit protection from influenza infection is still unknown.

Etanercept (brand name, Enbrel), an anti-TNF- $\alpha$ agent, is a fusion protein of the human p75 TNF- $\alpha$ receptor attached to the Fc portion of human IgG1 [17], which has been approved for the treatment of rheumatoid arthritis $[18,19]$. However, no evidence supports the protective effects of etanercept against influenza infection.

In this study, a murine model of lethal acute respiratory H1N1 influenza A infection and etanercept was used to investigate the immunoregulatory role of TNF- $\alpha$ in viral clearance, host immune responses, and lung immunopathology. For the first time, our study demonstrated that the inhibition of TNF- $\alpha$ had a significant effect on the extent of lung immunopathology and inhibited inflammatory cellular infiltration and cytokine responses. In addition, we observed a decrease in influenza virus replication and an increased survival of influenza virus-infected mice.

\section{Materials and methods}

\section{Experimental infection of mice with a mouse-adapted} H1N1 influenza virus

$\mathrm{BALB} / \mathrm{c}$ male mice (16 to $18 \mathrm{~g}$ ) were purchased from the Shanghai SLACCAS Laboratory Animal Co., Ltd. (Shanghai, China). Mice were housed under specific pathogen-free conditions and given free access to sterile water and standard mouse food. All experimental protocols were approved by the Animal Experiment Ethics Committee of Fudan University (Shanghai, China).

The influenza virus strain A/FM/1/47 (H1N1) used in this study is a highly virulent, mouse-adapted virus that was isolated from patients at Fort Monmouth, NJ, USA, during an outbreak in 1947. The virus can cause severe pneumonia and high mortality in mice (ATCC VR-97). The virus was supplied by the Shanghai Center for Disease Control and Prevention (Shanghai, China) and was stored in aliquots at $-70^{\circ} \mathrm{C}$. A freshly thawed aliquot was used for each experiment [20]. The TNF- $\alpha$ inhibitor etanercept was obtained from Beijing SL Pharmaceutical Co., Ltd. (Beijing, China).

Mice under isoflurane anesthesia were infected intranasally (i.n.) with $10 \mathrm{TCID}_{50}$ of A/FM/1/47 (H1N1) [21]. Two hours after infection, mice were i.n. (local administration for respiratory system) inoculated with either 30 $\mu \mathrm{l}$ of $0.9 \%$ (wt/vol) $\mathrm{NaCl}$ (virus control) or $2.5 \mathrm{mg} / \mathrm{kg}$ of etanercept (dissolved in $0.9 \%(\mathrm{wt} / \mathrm{vol}) \mathrm{NaCl}$ ) twice daily. An uninfected control group of mice also received $0.9 \%$ (wt/vol) $\mathrm{NaCl}$ in the same manner.

\section{Mice survival and body-weight loss}

For the survival study ( $n=10$ mice per group), etanercept or virus control was administered as described for 7 days. Then, mice were continuously monitored for survival and body-weight loss for an additional 7 days. These experiments were repeated 3 times, and we made related calculations.

\section{Histopathology}

For histopathologic analysis, experimental infections as described earlier were performed. On day 4 after infection, mice ( $n=6$ per group) were euthanized and weighed. Lung tissues were harvested and weighed, and the corresponding lung/body index was calculated. The left lobes of the lung were immersed in PBS-buffered formalin, and were then preserved in paraffin blocks by using standard procedures. Tissue sections $(10 \mu \mathrm{m})$ were cut, placed on glass slides, and stained with hematoxylin and eosin by using standard techniques.

A tissue-inflammation score was assigned to the analyzed sections of each lung by using the mean score obtained from six separate random fields per tissue section. Scores were assigned according to the percentage of lung pathologic congestive involvement, as follows: none, 0 ; $\leq 25 \%, 1$; $26 \%$ to $50 \%, 2 ; 51 \%$ to $75 \%, 3$; and $\geq 76 \%, 4$.

Microscopic analysis was carried out by three separate pathologists who were blinded to the various experimental treatments.

\section{Inflammatory cytokine measurement}

On days 2 and 4 after infection, mice ( $n=6$ per group) were euthanized, and lung tissues were harvested. These tissues were individually homogenized in PBS buffer, and the supernatants were used for inflammatory cytokine measurement. The quantities of TNF- $\alpha$, IFN- $\gamma$, and IL- 6 were determined by using commercial enzyme-linked immunosorbent assay (ELISA) kits (BD Biosciences) by following the manufacturer's instructions. The average level of inflammatory cytokines was calculated according to these data from three separate experiments. 
Infiltrate immune cell analysis with flow cytometry

On days 2 and 4 after infection, mice ( $n=4$ per group) were euthanized. Lungs were harvested and diced by using surgical scissors. Diced tissue was suspended in 4 $\mathrm{ml}$ of DMEM containing $0.5 \mathrm{mg} / \mathrm{ml}$ collagenase from Clostridium histolyticum type IV (Sigma, USA), $50 \mathrm{U} / \mathrm{ml}$ DNase I (Sigma), and $1 \mathrm{mg} / \mathrm{ml}$ trypsin inhibitor type II-s (Sigma) for 1 hour at $37^{\circ} \mathrm{C}$. The suspension was then crushed through a $40-\mu \mathrm{m}$ basket filter, and unwanted red blood cells were lysed by using red blood cell lysis buffer containing 0.02 Tris- $\mathrm{HCl}(\mathrm{pH}$ 7.4) and 0.14 $\mathrm{NH}_{4} \mathrm{Cl}$. Inflammatory cells were purified by centrifugation in 35\% (vol/vol) PBS-buffered Percoll (GE Healthcare Life Sciences, USA) at $500 \mathrm{~g}$ for 15 minutes. Cell pellets were resuspended in staining buffer (RPMI-1640 medium), and Fc receptors were blocked by using $25 \mu \mathrm{g} / \mathrm{ml}$ anti-mouse CD16/32. Cells were stained with fluorescently labeled

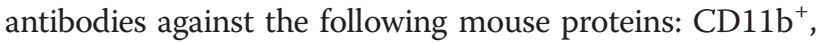
$\mathrm{F}_{480}$, $\mathrm{Ly} 6 \mathrm{G}^{+}$(neutrophils), $\mathrm{CD}_{11 \mathrm{~b}^{+}}, \mathrm{F} 480^{+}$, and $\mathrm{Ly} 6 \mathrm{G}^{-}$ (macrophage/monocytes), CD3e, $\mathrm{CD}^{-} 9 \mathrm{~b}^{+}$[natural killer (NK) cells], CD3e $\mathrm{e}^{+}, \mathrm{CD} 19^{+}$(B cells), CD3e $\mathrm{e}^{+}, \mathrm{CD} 4^{+}$ (T-helper cells), CD3e $\mathrm{e}^{+}$, and $\mathrm{CD}^{+} \mathrm{a}^{+}$(cytotoxic $\mathrm{T}$ cells) $[22,23]$. All antibodies were purchased from BD Biosciences (USA). The average counting of immune cells was calculated from three separate experiments.

\section{Inflammatory signaling pathways (Toll-like receptors and} NF-KB) and influenza virus replication

On days 2 and 4 after infection, mice ( $n=6$ per group) were euthanized, and lung tissues were harvested. These left-lung lobes were homogenized for RNA isolation. The isolation of total RNA and cDNA synthesis were performed by using the Trizol reagent (Invitrogen) and PrimeScript RT reagent Kit (DRR047A; Takara) according to the manufacturers' recommendations. The primers for TLR-3, TLR-4, TLR-7, MyD88, TRIF, NF- $\kappa B$, the influenza virus $M$ gene, and glyceraldehyde 3-phosphate dehydrogenase (GAPDH) were as described in Additional file 1. By using cDNAs as templates, quantitative real-time PCR was carried out by using the SYBR Green PCR Master Mix (Applied Biosystems) in a StepOne Plus Real-Time PCR Detection System (Applied Biosystems), according to the manufacturer's instructions and with the following thermocycling parameters: $94^{\circ} \mathrm{C}$ for 5 minutes; followed by $94^{\circ} \mathrm{C}$ for 5 seconds, $60^{\circ} \mathrm{C}$ for 30 seconds for 40 cycles, with a final melting curve analysis of $60^{\circ} \mathrm{C}$ to $95^{\circ} \mathrm{C}$. The mRNA expression levels were normalized to the corresponding expression level of the GAPDH housekeeping gene. The results of qPCR were from three separated independent experiments.

The remaining right-lung lobes were used for immunohistochemistry. Tissue sections $(10 \mu \mathrm{m})$ were cut and processed as described earlier. The primary antibody, phospho-NF-kB p65 (Ser536) (93H1) rabbit monoclonal antibody (Cell Signaling Technology, Inc., USA) was used to evaluate the activation of the inflammatory NF- $\mathrm{kB}$ signaling pathway.

\section{Statistical analyses}

All statistical analyses were performed by using GraphPad Prism for Windows (Version 6.0). The Gehan-BreslowWilcoxon test was used to analyze the survival of mice, whereas the one-way ANOVA was used to analyze other experimental data. In all cases, probability values less than $0.05(P<0.05)$ were taken to indicate statistical significance.

\section{Results}

Administration of the TNF- $a$ inhibitor etanercept significantly improved survival of H1N1-infected mice and reduced pulmonary injury

Mice were treated with either saline or etanercept i.n. after intranasal infection with the lethal mouse-adapted human influenza virus A/FM/1/47 (H1N1). Etanercept administration significantly increased the survival of mice, compared with the control mice (Figure 1A). For recipients of saline alone, no mice survived beyond 7 days after infection, whereas $30 \%$ of mice that received etanercept survived until 14 days after infection, which was the end of the observation period $(P<0.01)$. In mice treated with etanercept, body-weight loss ceased on day 4 after infection and slowly recovered until the end of the experiment at day $14(P<0.05$; Figure $1 \mathrm{~B})$. Obvious individual differences were also observed in etanercept-treated mice after 7 days, and whether they were related to ceasing of etanercept will be clarified in future work.

Lung/body index (Figure 1C) demonstrated that infection with $\mathrm{H} 1 \mathrm{~N} 1$ caused lung-tissue swelling and the production of significant amounts of exudate in the control mice. The administration of etanercept significantly alleviated lung swelling and exudate, an observation that was confirmed by the histopathologic analysis. Histopathologic analysis of lungs from the infected mice treated with etanercept revealed markedly reduced tissue injury, mononuclear cell accumulation, hemorrhage, and pulmonary edema (Figure $1 \mathrm{E}$ through $\mathrm{H}$ ). In addition, etanercept significantly reduced tissue-inflammation scores compared with control mice on day 4 after infection (Figure 1D).

\section{Etanercept inhibited the burst of inflammatory cytokines and the recruitment of innate immune cells induced by lethal influenza virus infection}

Robust innate proinflammatory cytokine expression can cause direct tissue insult and recruit potentially tissuedestructive inflammatory cells. We selected three important inflammatory cytokines (TNF- $\alpha$, IL-6, and IFN- $\gamma$ ) to evaluate the cytokine burst in lethally influenza-infected mice. ELISA results revealed that these cytokines increased 


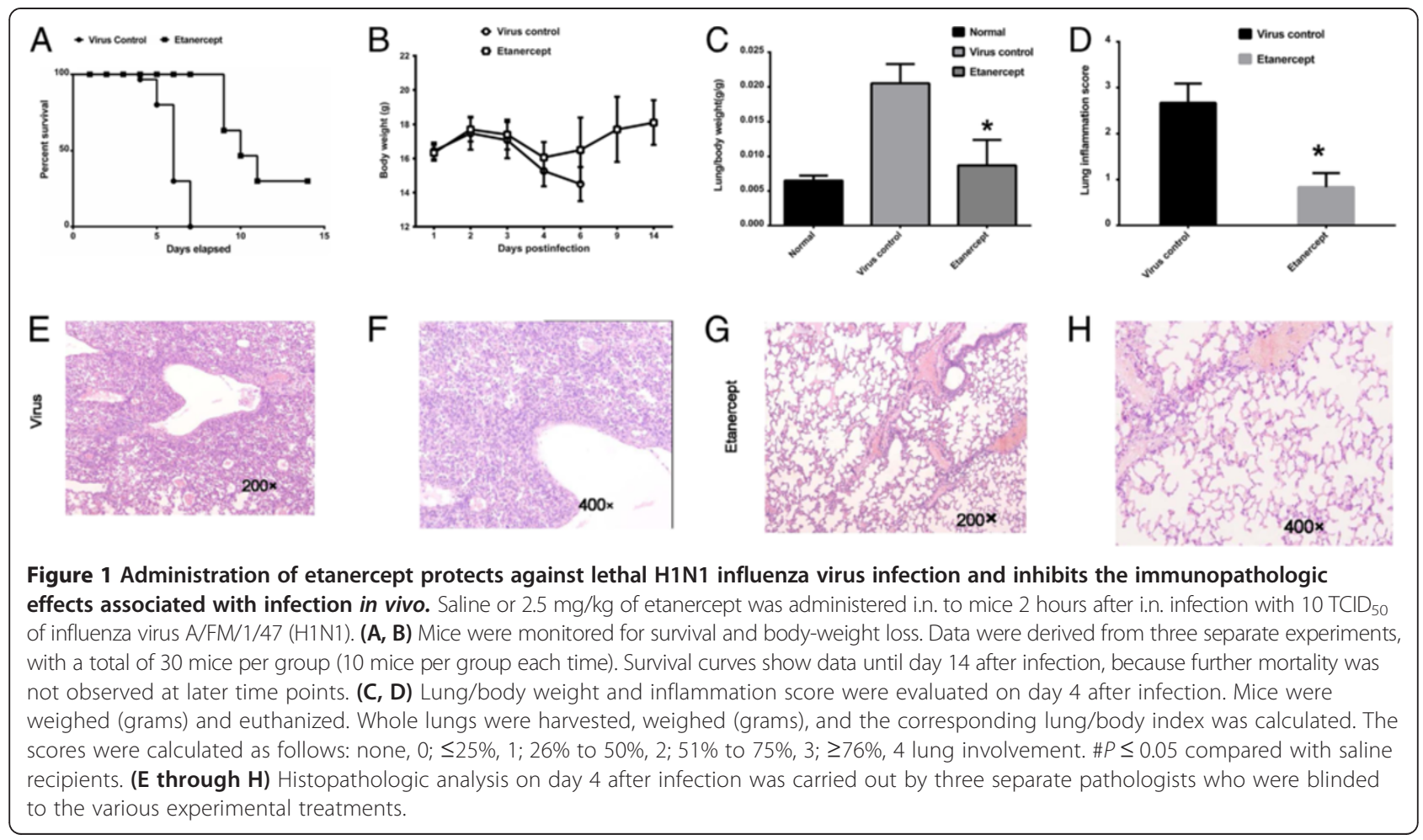

in the virus-infected control mice as expected, but they were significantly inhibited in mice treated with etanercept (Figure 2A). The recruitment and infiltration of immune cells can be affected by inflammatory cytokine production. Analysis with flow cytometry revealed a consistent reduction in the accumulation of macrophage/monocytes (Figure 2B) and neutrophils (Figure 2C) in the lungs of mice treated with etanercept on 2 and 4 days after influenza A virus infection. Many significant differences were noted in neutrophils accumulation between virus control and etanercept-treated mice. The NK cell, an innate immune cell that plays an important role in controlling and clearing virus, count significantly decreased after infection. The administration of etanercept counteracted this reduction in NK cells (Figure 2D). At these same time points, the adaptive immune cells $\left(\mathrm{CD} 4^{+}\right.$Th cells and $\mathrm{CD} 8^{+}$Tc cells) were also evaluated, but no clear influences of etanercept were observed in mice at days 2 and 4 after infection (Figure 2E through G). Even etanercept seems to alleviate the reduction of $B$ cells after infection, but the possible influence of etanercept on adaptive immune responses must be explored in future work.

In agreement with the observations of diminished inflammation and pulmonary injury after influenza virus infection (Figure $1 \mathrm{C}$ through $1 \mathrm{H}$ ), etanercept significantly inhibited inflammatory cytokine production as well as the accumulation of innate inflammatory infiltrates.
Etanercept inhibited the activation of the NF-KB signaling pathway and enhanced host control of influenza virus replication

Before these experiments, we already used a pair of housekeeping genes GAPDH and beta-actin to assess these gene expressions under etanercept treatment, and we found the normalized results were consistent.

NF- $\mathrm{kB}$ (nuclear factor kappa B) family transcription factors are master regulators of immune and inflammatory processes in response to both injury and infection. Toll-like receptors (TLRs) recognize specific pathogenassociated molecular patterns (PAMPs) and can trigger the activation of the NF-kB pathway. In this study, we monitored the transcriptional levels of TLR3/7 (specific for viruses), TLR4, and the downstream adaptor genes $M y D 88$ and TRIF, and NF- $\kappa B$ p 65 .

Data from the qPCR revealed that administration of etanercept resulted in a reduced upregulation of the virus-specific TLR3 and TLR7 in mice induced by lethal influenza virus infection (Figure $3 \mathrm{~A}$ and $\mathrm{C}$ ), consistent with the decreased virus replication in mice treated with etanercept (Figure 3G). This indicated that the administration of etanercept enhanced the host control of influenza virus replication. Interestingly, the mRNA level of TLR4, the typical lipopolysaccharide (LPS) recognition receptor, was dramatically increased in virus-infected mice, which suggests that influenza virus infection resulting in complicated cross-activations, including the activation of TLR4, was also inhibited by etanercept (Figure 3B). 

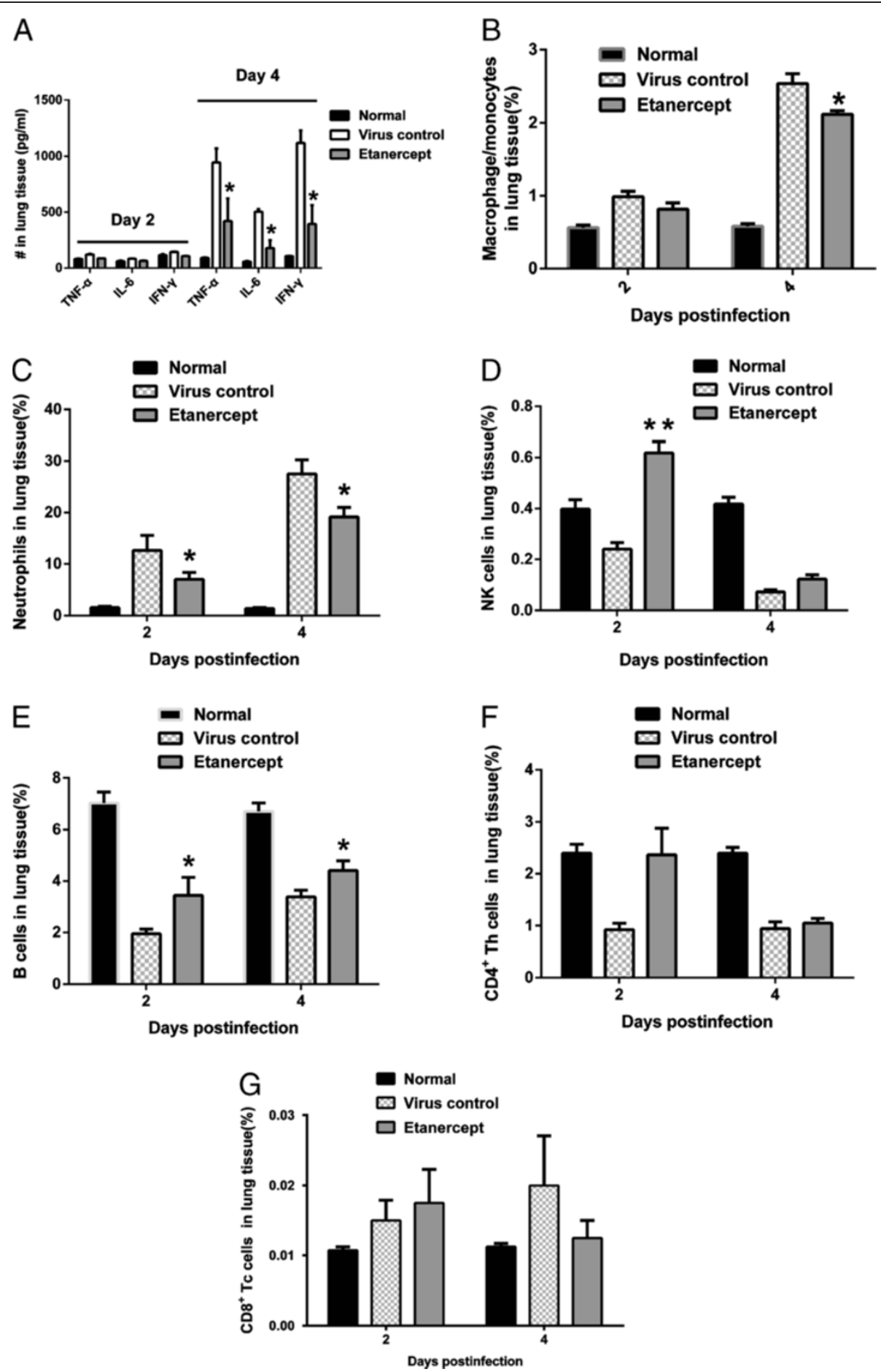

Figure 2 Etanercept reduced inflammatory cells infiltration and dampened the production of pro-inflammatory cytokines. On days 2 and 4 after infection, mice were euthanized, and the lungs were harvested to be homogenized individually and assayed for the following. (A) Inflammatory cytokines (TNF-a, IFN-y, IL-6) were analyzed with ELISA. (B through G) Major immune cells (macrophage/monocytes, neutrophils, NK cells, B cells, CD4 $4^{+}$Th cells, and CD8 ${ }^{+}$Tc cells) were analyzed with flow cell cytometry. Four samples were picked up from mice per group each time for assaying, and three replicated experiments were conducted. Data are presented as mean \pm SD. \#P $\leq 0.05$ compared with saline recipients. 

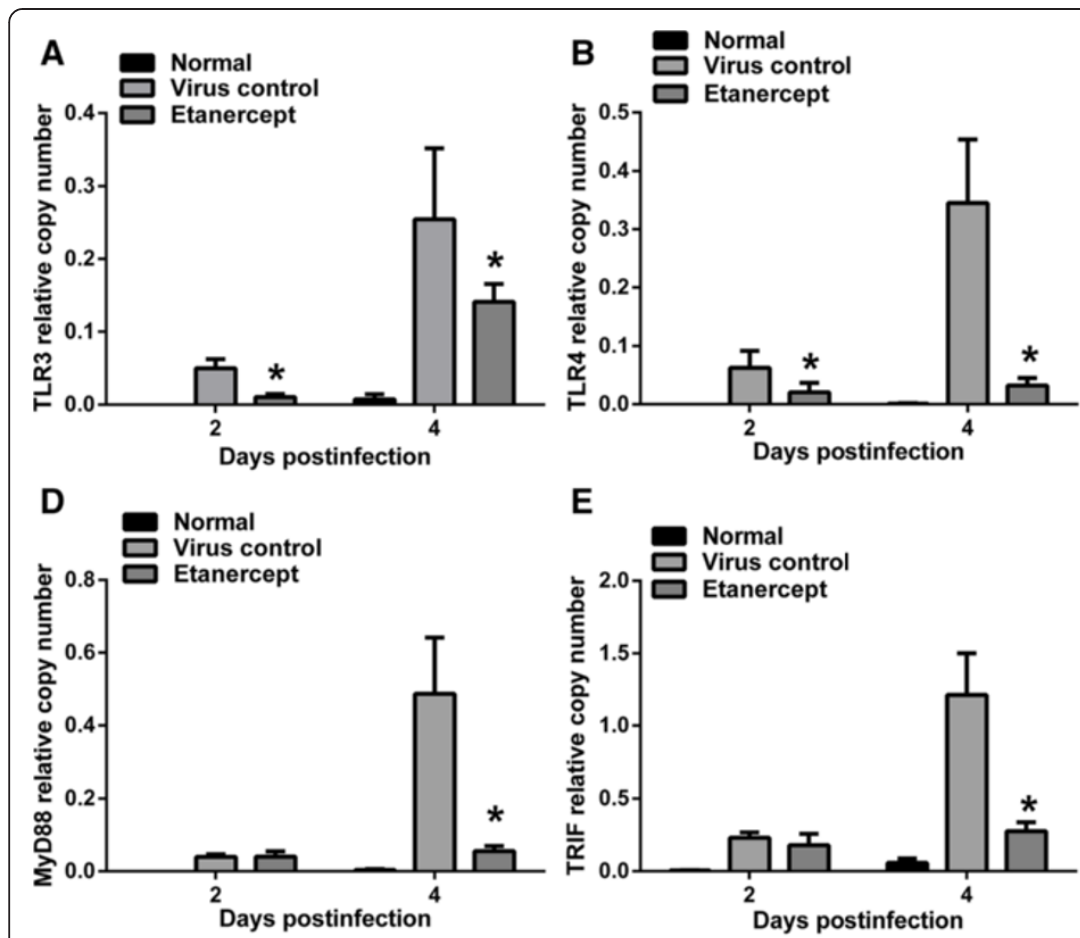

E
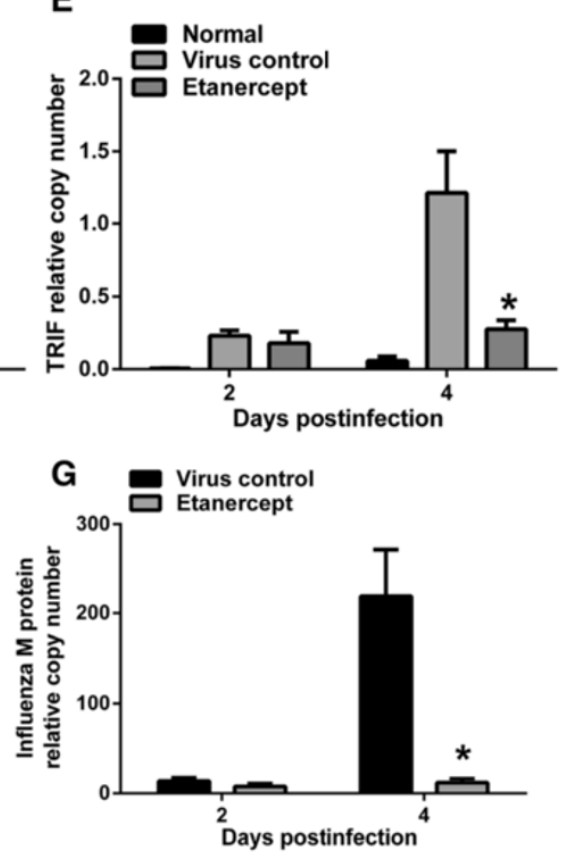

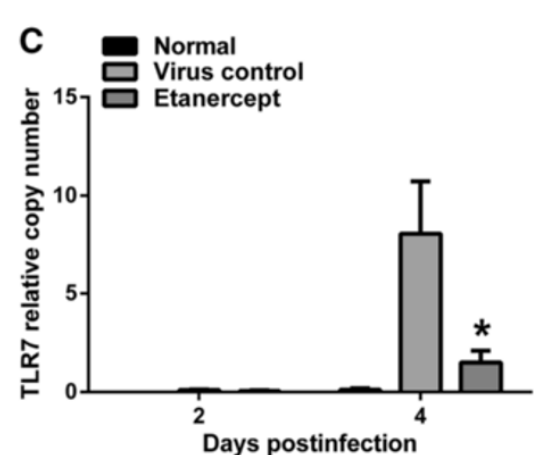

$\mathbf{F}$

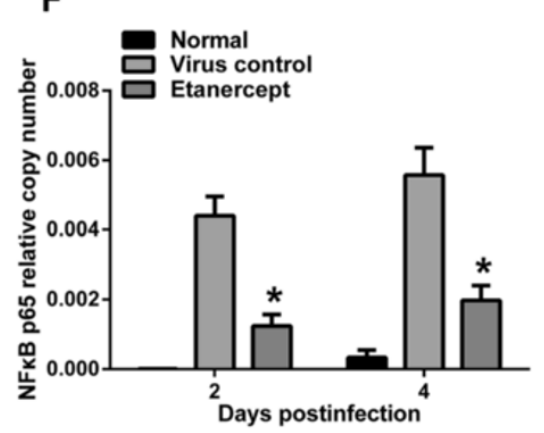

H
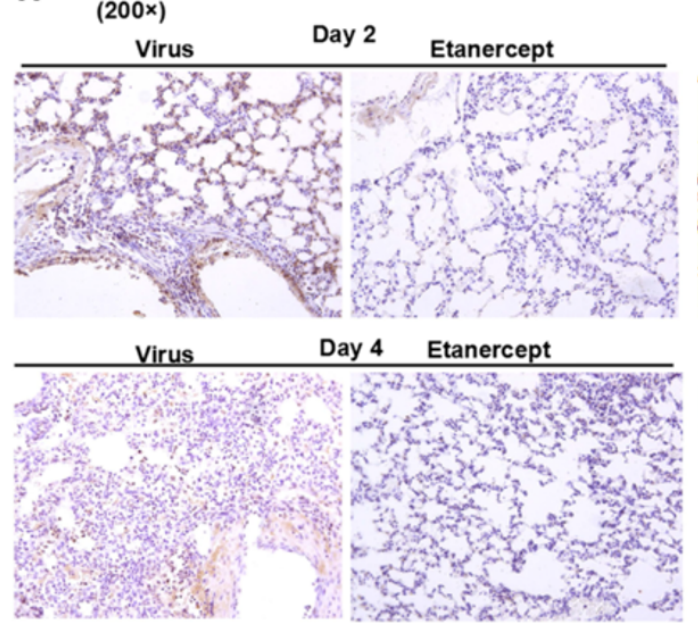

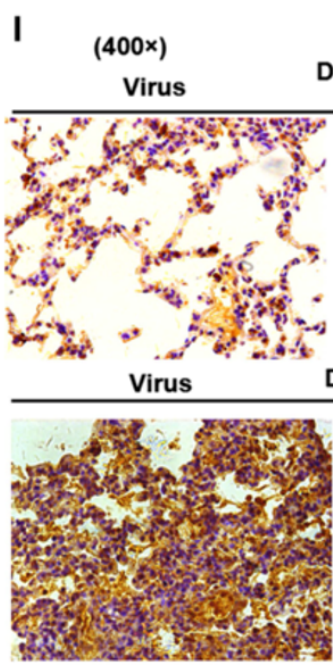

Day 2

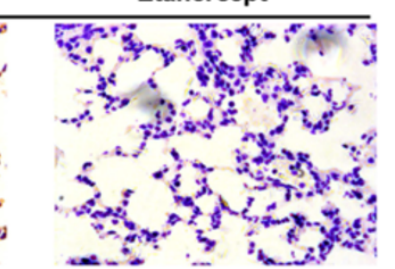

Day 4 Etanercept

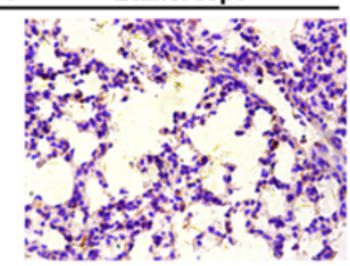

Figure 3 Etanercept inhibited the TLRs-NF-KB signaling pathway and enhanced host control of influenza replication. On days 2 and 4 after infection, mice were euthanized, and the lungs were harvested and assayed for the following: (A through C) Relative mRNA levels of TLR3, TLR4, and TLR7. (D through F) The cascade genes (MyD88, TRIF, NF-KB, p65) in the NF-KB pathway. (G) Influenza M gene, indicating the replication of influenza virus. (H through I) Immunohistochemical assay for phosphorylation of NF-KB p65 (dark yellow staining). The level of dark yellow staining indicates the activation of the NF-KB signaling pathway. Data are presented as mean $\pm \mathrm{SD}$. \#P $\leq 0.05$ compared with saline recipients. 
The overexpressed TLRs triggered the activation of the NF-kB signaling pathway, which was significantly influenced by etanercept administration, as seen by the downregulated mRNAs of $M y D 88, T R I F$, and NF- $K B$ p 65 in etanercept-treated mice (Figure 3D-F). The immunohistochemical results also clearly showed the phosphorylation of the NF- $\mathrm{kB}$ p 65 protein, indicating the activation of the NF- $\mathrm{kB}$ signaling pathway in influenza virus-infected mice. In contrast, etanercept significantly reduced the phosphorylation of NF-kB p65 (Figure 3H through 3I).

These data strongly suggest that TNF- $\alpha$ may play an important role in the burst of inflammatory cytokines, recruitment of innate immune cells, and activation of the NF- $\kappa B$ signaling pathway. Blocking TNF- $\alpha$ resulted in improved survival and alleviated lung inflammation in influenza-infected mice.

\section{Discussion}

TNF- $\alpha$ is traditionally considered a pro-inflammatory cytokine [24,25]; however, recent emerging evidence also identified an immune-regulatory role for it [26-28]. TNF- $\alpha$ blockers, such as infliximab, adalimumab, certolizumab pegol, golimumab, and etanercept, have been approved for the treatment of rheumatoid arthritis and other immune-mediated diseases. Thus, an interest exists in investigating the use of inhibitors of TNF- $\alpha$ in the treatment of infectious diseases [29,30].

In this study, we built up a simple and lethal influenzainfection mice model to evaluate the effects of TNF inhibitors in influenza virus-induced severe viral pneumonia. We administered etanercept to mice i.n. for a short period (7 days). The results showed that local inhibition of TNF$\alpha$ could significantly reduce the high mortality in mice induced by lethal influenza infection, which indicated that TNF- $\alpha$ in lung tissue might play a pathologic role in severe virus infection. Even intranasal administration of etanercept (limited to the respiratory system) has been proved to be effective for lethal influenza infection in this research. Much remains to be investigated, such as patient screening and possible second bacterial infections.

Many cytokines/chemokines are essential for the control of virus replication but also exacerbate morbidity and tissue injury in mouse models [6]. IFN- $\gamma$ activates inflammatory cells and stimulates the expression of multiple cytokines and chemokines [31-33]. IL-6 expression is directly linked to host morbidity [34,35], whereas TNF- $\alpha$ secretion enhanced pulmonary injury. In this study, a burst of IFN- $\gamma$, IL- 6 , and TNF- $\alpha$ was observed in lethal influenza virus-infected mice, especially on day 4 after infection. Blocking TNF- $\alpha$ obviously inhibited the overproduction of these inflammatory cytokines, which was consistent with the reduced lung injury and low mortality in mice treated with etanercept. The transcriptional and protein levels of other cytokines and chemokines still must be determined to assess the influence of etanercept.

Innate and adaptive immune cell infiltration contributes to lung inflammation. Our study showed that blocking TNF- $\alpha$ by using etanercept inhibited a large number of infiltrated neutrophils and macrophage/monocytes in influenza virus-infected mice. These results are similar to the findings on the functional roles of macrophages/ neutrophils in virus replication and mortality [36]. Which kind of cell in lung tissue is targeted mainly by etanercept is under consideration in our future work. The influence on other immune cells such as $\mathrm{NK}, \mathrm{B}, \mathrm{CD} 4^{+}$, and $\mathrm{CD} 8^{+}$ cells on days 2 and 4 after infection was not so clear in mice treated with etanercept, and so more-detailed future studies will be performed at day 7 (and later) after infection to clarify this observation.

The NF-kB signaling pathway is a key factor controlling inflammatory cytokine secretion and inflammatory cell recruitment during virus infection. In this study, significant activation of the NF- $\mathrm{kB}$ signaling pathway was observed on days 2 or 4 after infection. This activation was inhibited in mice treated with etanercept. TNF- $\alpha$ can trigger the activation of the NF- $\mathrm{kB}$ signaling pathway via binding to tumor necrosis factor receptor (TNFR) [37], and so blocking TNF- $\alpha$ might inhibit the activation of NF- $\kappa B$. Toll-like receptors may activate the signaling cascade in the NF-kB signaling pathway. The upregulation of TLR4, which recognizes oxidized phospholipids generated by reactive oxygen species (ROS) [38], was evidently inhibited in etanercept-treated mice. This indicated that blocking TNF- $\alpha$ might also alleviate influenza virus-induced inflammatory injury. But whether the reduction of TLR4 is related to etanercept immunoadhesion is still unclear, and it will be explored in our future work. The inhibited virus-specific TLR3/7 correlated with reduced influenza replication ( $M$ gene) in mice treated with etanercept, which indicated that blocking TNF- $\alpha$ enhanced host control of virus replication, but the elucidation of a possible mechanism requires more experimental investigation.

\section{Conclusions}

In summary, blocking TNF- $\alpha$ by using etanercept suppressed the immunopathology and mortality in lethal influenza-infected mice. These effects may be ascribed to the inhibition of the cytokine bursts, reduced inflammatory cell infiltration, and downregulation of NF- $\mathrm{KB}$ signaling pathways.

This is the first attempt at etanercept use in influenza virus-induced viral pneumonia, and more details must be clarified, such as the influences of IFN system, adaptive immune responses, and different virus strains.

We envision that the use of etanercept (or other TNF antagonists), in combination with antiviral strategies, may be an effective tool against morbidity and mortality 
induced by seasonal and pandemic strains of influenza A virus.

\section{Key messages}

- TNF- $\alpha$ inhibitor etanercept significantly improved survival and limited the lung inflammation in lethal influenza-infected mice.

- Blocking TNF- $\alpha$ markedly inhibited the burst of major inflammatory cytokines (for example, IL-6, IFN- $\gamma$, and TNF- $\alpha$ ) in the lung tissue of influenzainfected mice.

- Blocking TNF- $\alpha$ reduced innate immune cell infiltration (macrophage/monocytes and neutrophils) in mouse lung tissue.

- Blocking TNF- $\alpha$ enhanced host control of influenza virus replication.

- Blocking TNF- $\alpha$ downregulated the mRNA of Toll-like receptors and inhibited the activation of NF-kB signaling pathways.

\section{Additional file}

Additional file 1: Table S1. The primers for quantitative real time $P C R$ These RT primers for $M$ gene, TLR3, TLR-4, TLR-7, MyD88, TRIF, NF-KB, $p 65$, and GAPDH analysis. Using CDNAs as the template, quantitative real-time PCR was carried out by using the SYBR Green PCR Master Mix (Applied Biosystems) in a StepOne Plus Real-Time PCR Detection System (Applied Biosystems), according to the manufacturer's instructions. The mRNA expression levels were normalized to the corresponding expression level of the GAPDH housekeeping gene.

\section{Abbreviations}

i.n.: Intranasally; IFN-ү: interferon gamma; IL-6: interleukin 6; NF-KB: nuclear factor kappa B; NK cell: natural killer cell; Tc cell: cytotoxic T cell; Th cell: T-helper cell; TLR: Toll-like receptor; TNF-a: tumor necrosis factor alpha.

\section{Competing interests}

The authors declare that they have no competing interests.

\section{Authors' contributions}

XLS carried out all in vitro and in vivo experiments in this study and drafted the manuscript. WZ and HH carried out the immunoassays. HGZ performed the histopathology analysis. PZ participated in the design of the study and performed the statistical analysis. HYZ and DWJ conceived the study, participated in its design and coordination, and helped to draft the manuscript. All authors read and approved the final manuscript.

\section{Acknowledgements}

This work was supported by grants from the Shanghai Science and Technology Funds (Nos. 09ZR1403200), National Natural Science Foundation of China (81102359), and the National Science and Technology Major Project for Drug Discovery of the Ministry of Science and Technology of China (Nos. 2011ZX09102-001-27). We thank Medjaden Bioscience Limited for assisting in the preparation of this manuscript.

\section{Author details}

${ }^{1}$ Department of Biosynthesis, School of Pharmacy, Fudan University, 826 Zhangheng Road, Shanghai 201203, China. ²Department of Chemistry, Fudan University, 220 Han Dan Road, Shanghai 200433, China. ${ }^{3}$ Department of Pathology, Shanghai Medical College, Fudan University, 138 Yi Xue Yuan Road, Shanghai 200032, China.
Received: 20 August 2013 Accepted: 10 December 2013

Published: 27 December 2013

\section{References}

1. Paterson D, Fodor E: Emerging roles for the influenza A virus nuclear export protein (NEP). PLoS Pathog 2012, 8:e1003019.

2. Liu D, Shi W, Shi Y, Wang D, Xiao H, Li W, Bi Y, Wu Y, Li X, Yan J, Liu W, Zhao G, Yang W, Wang Y, Ma J, Shu Y, Lei F, Gao GF: Origin and diversity of novel avian influenza A H7N9 viruses causing human infection: phylogenetic, structural, and coalescent analyses. Lancet 2013, 381:1926-1932.

3. Dai C, Jiang M: Understanding H7N9 avian flu. BMJ 2013. doi:10.1136/bmj. f2755.

4. Derek G: The 2009 H1N1 influenza outbreak in its historical context. J Clin Virol 2009, 45:174-178.

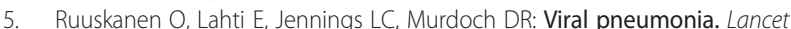
2011, 9773:1264-1275

6. La Gruta NL, Kedzierska K, Stambas J, Doherty PC: A question of self preservation: immunopathology in influenza virus infection. Immunol Cell Biol 2007, 85:85-92.

7. Smith AM, Adler FR, Ribeiro RM, Gutenkunst RN, McAuley JL, McCullers JA, Perelson AS: Kinetics of coinfection with influenza A virus and Streptococcus pneumoniae. PLoS Pathog 2013, 9:e1003238.

8. Tscherne DM, García-Sastre A: Virulence determinants of pandemic influenza viruses. J Clin Invest 2011, 121:6-13.

9. Zheng BJ, Chan KW, Lin YP, Zhao GY, Chan C, Zhang HJ, Chen HL, Wong SS, Lau SK, Woo PC, Chan KH, Jin DY, Yuen KY: Delayed antiviral plus immunomodulator treatment still reduces mortality in mice infected by high inoculum of influenza A/H5N1 virus. Proc Natl Acad Sci U S A 2008, 105:8091-8096.

10. Falagas ME, Vouloumanou EK, Baskouta E, Rafailidis PI, Polyzos K, Rello J: Treatment options for $2009 \mathrm{H} 1 \mathrm{~N} 1$ influenza: evaluation of the published evidence. Int J Antimicrob Agents 2010, 35:421-430.

11. Carter MJ: A rationale for using steroids in the treatment of severe cases of H5N1 avian influenza. J Med Microbiol 2007, 56:875-883.

12. Walsh KB, Teijaro JR, Wilker PR, Jatzek A, Fremgen DM, Das SC, Watanabe T, Hatta M, Shinya K, Suresh M, Kawaoka Y, Rosen H, Oldstone MB: Suppression of cytokine storm with a sphingosine analog provides protection against pathogenic influenza virus. Proc Natl Acad Sci U S A 2011, 108:12018-12023.

13. Iwasaki A, Medzhitov R: A new shield for a cytokine storm. Cell 2011, 146:861-862.

14. Cillóniz C, Shinya K, Peng X, Korth MJ, Proll SC, Aicher LD, Carter VS, Chang JH, Kobasa D, Feldmann F, Strong JE, Feldmann H, Kawaoka Y, Katze MG: Lethal influenza virus infection in macaques is associated with early dysregulation of inflammatory related genes. PLOS Pathog 2009, 5:e1000604.

15. de Jong MD, Simmons CP, Thanh TT, Hien VM, Smith GJ, Chau TN, Hoang DM, Chau NV, Khanh TH, Dong VC, Qui PT, Cam BV, Ha do Q, Guan Y, Peiris JS, Chinh NT, Hien TT, Farrar J: Fatal outcome of human influenza A (H5N1) is associated with high viral load and hypercytokinemia. Nat Med 2006, 12:1203-1207.

16. Bermejo-Martin JF, Ortiz De Lejarazu R, Pumarola T, Rello J, Almansa R, Ramírez P, Martin-Loeches I, Varillas D, Gallegos MC, Serón C, Micheloud D, Gomez JM, Tenorio-Abreu A, Ramos MJ, Molina ML, Huidobro S, Sanchez E, Gordón M, Fernández V, Del Castillo A, Marcos MA, Villanueva B, López CJ, Rodríguez-Domínguez M, Galan JC, Cantón R, Lietor A, Rojo S, Eiros JM, Hinojosa C, Gonzalez I, Torner N, Banner D, Leon A, Cuesta P, Rowe T, Kelvin DJ: Th1 and Th17 hypercytokinemia as early host response signature in severe pandemic influenza. Crit Care 2009, 13:R201.

17. FDA: Etancercept (Enbrel). Available at http://www.fda.gov/downloads/ Drugs/DevelopmentApprovalProcess/HowDrugsareDevelopedandApproved/ ApprovalApplications/TherapeuticBiologicApplications/ucm088697.pdf (accessed 13February 2012).

18. Martin PL, Bugelski PJ: Concordance of preclinical and clinical pharmacology and toxicology of monoclonal antibodies and fusion proteins: soluble targets. Br J Pharmacol 2012, 166:806-822.

19. Smolen JS, Nash $P$, Durez $P$, Hall S, Ilivanova E, Irazoque-Palazuelos $F$, Miranda P, Park MC, Pavelka K, Pedersen R, Szumski A, Hammond C, Koenig AS, Vlahos B: Maintenance, reduction, or withdrawal of etanercept after treatment with etanercept and methotrexate in patients with moderate rheumatoid arthritis (PRESERVE): a randomised controlled trial. Lancet 2013, 381:918-929. 
20. Michelle DT, Emma RJ, Andrew GB, Patrick CR: Glycosylation of the hemagglutinin modulates the sensitivity of H3N2 influenza viruses to innate proteins in airway secretions and virulence in mice. Virology 2011, 413:84-92.

21. Liu K, Yao Z, Zhang L, Li J, Xing L, Wang X: MDCK cell-cultured influenza virus vaccine protects mice from lethal challenge with different influenza viruses. Appl Microbiol Biotechnol 2012, 94:1173-1179.

22. Teijaro JR, Walsh KB, Cahalan S, Fremgen DM, Roberts E, Scott F, Martinborough E, Peach R, Oldstone MB, Rosen H: Endothelial cells are central orchestrators of cytokine amplification during influenza virus infection. Cell 2011, 146:979-990.

23. Wang J, Li F, Zheng M, Sun $R$, Wei $H$, Tian Z: Lung natural killer cells in mice: phenotype and response to respiratory infection. Immunology 2012, 137:37-47.

24. Aggarwal BB: Signalling pathways of the TNF superfamily: a double-edged sword. Nat Rev Immunol 2003, 3:745-756.

25. Hehlgans T, Pfeffer $K$ : The intriguing biology of the tumor necrosis factor/ tumour necrosis factor receptor superfamily: players, rules and the games. Immunology 2005, 115:1-20.

26. Suresh $M$, Singh A, Fischer $C$ : Role of tumor necrosis factor receptors in regulating CD8 T-cell responses during acute lymphocytic choriomeningitis virus infection. J Virol 2005, 79:202-213.

27. Singh $A$, Wuthrich $M$, Klein $B$, Suresh $M$ : Indirect regulation of CD4 T-cell responses by tumor necrosis factor receptors in an acute viral infection J Virol 2007, 81:6502-6512.

28. Damjanovic D, Divangahi M, Kugathasan K, Small CL, Zganiacz A, Brown EG, Hogaboam CM, Gauldie J, Xing Z: Negative regulation of lung inflammation and immunopathology by TNF-a during acute influenza infection. Am J Pathol 2011, 179:2963-2976.

29. Campbell J, Lowe D, Sleeman MA: Develoeping the next generation of monoclonal antibodies for the treatment of rheumatoid arthritis. Br J Pharmacol 2011, 162:1470-1484.

30. Caprioli F, Caruso R, Sarra M, Pallone F, Monteleone G: Disruption of inflammatory signals by cytokine-targeted therapies for inflammatory bowel diseases. Br J Pharmacol 2011, 165:820-828.

31. Sirén J, Sareneva T, Pirhonen J, Strengell M, Veckman V, Julkunen I, Matikainen S: Cytokine and contact-dependent activation of natural killer cells by influenza A or Sendai virus-infected macrophages. J Gen Virol 2004, 85:2357-2364.

32. Galligan CL, Murooka TT, Rahbar R, Baig E, Majchrzak-Kita B, Fish EN: Interferons and viruses: signaling for supremacy. Immunol Res 2006, 35:27-40

33. Billiau A, Heremans $\mathrm{H}$, Vermeire K, Matthys P: Immunomodulatory properties of interferon-gamma: an update. Ann N Y Acad Sci 1998, 856:22-32.

34. Kozak W, Poli V, Soszynski D, Conn CA, Leon LR, Kluger MJ: Sickness behavior in mice deficient in interleukin- 6 during turpentine abscess and influenza pneumonitis. Am J Physiol 1997, 272:R621-R630.

35. Kaiser L, Fritz RS, Straus SE, Gubareva L, Hayden FG: Symptom pathogenesis during acute influenza: interleukin- 6 and other cytokine responses. J Med Virol 2001, 64:262-268.

36. Tumpey TM, García-Sastre A, Taubenberger JK, Palese P, Swayne DE, Pantin-Jackwood MJ, Schultz-Cherry S, Solórzano A, Van Rooijen N, Katz JM, Basler CF: Pathogenicity of influenza viruses with genes from the 1918 pandemic virus: functional roles of alveolar macrophages and neutrophils in limiting virus replication and mortality in mice. J Virol 2005, 79:14933-14944

37. Napetschnig J, Wu H: Molecular basis of NF-kB signaling. Annu Rev Biophys 2013, 42:443-468.

38. Shirey KA, Lai W, Scott AJ, Lipsky M, Mistry P, Pletneva LM, Karp CL, McAlees J, Gioannini TL, Weiss J, Chen WH, Ernst RK, Rossignol DP, Gusovsky F, Blanco JC, Vogel SN: The TLR4 antagonist Eritoran protects mice from lethal influenza infection. Nature 2013, 497:498-502.

doi:10.1186/cc13171

Cite this article as: Shi et al:: Inhibition of the inflammatory cytokine tumor necrosis factor-alpha with etanercept provides protection against lethal H1N1 influenza infection in mice. Critical Care 2013 17:R301.

\section{Submit your next manuscript to BioMed Central and take full advantage of:}

- Convenient online submission

- Thorough peer review

- No space constraints or color figure charges

- Immediate publication on acceptance

- Inclusion in PubMed, CAS, Scopus and Google Scholar

- Research which is freely available for redistribution

Submit your manuscript at www.biomedcentral.com/submit
() Biomed Central 